\title{
Retinal Multipotent Stem-Cell Derived "MiEye" Spheroid 3D Culture Model for Preclinical Screening of Non-viral Gene Delivery Systems
}

\author{
Ding-Wen Chen and Marianna Foldvari ${ }^{\mathrm{a}}$
}

School of Pharmacy, University of Waterloo, 10 A Victoria St. S., Kitchener, ON N2G 1C5, Canada.

Submitted: July 1, 2018

Accepted: July 12, 2018;

Published July 19, 2018

\section{Graphical Abstract}

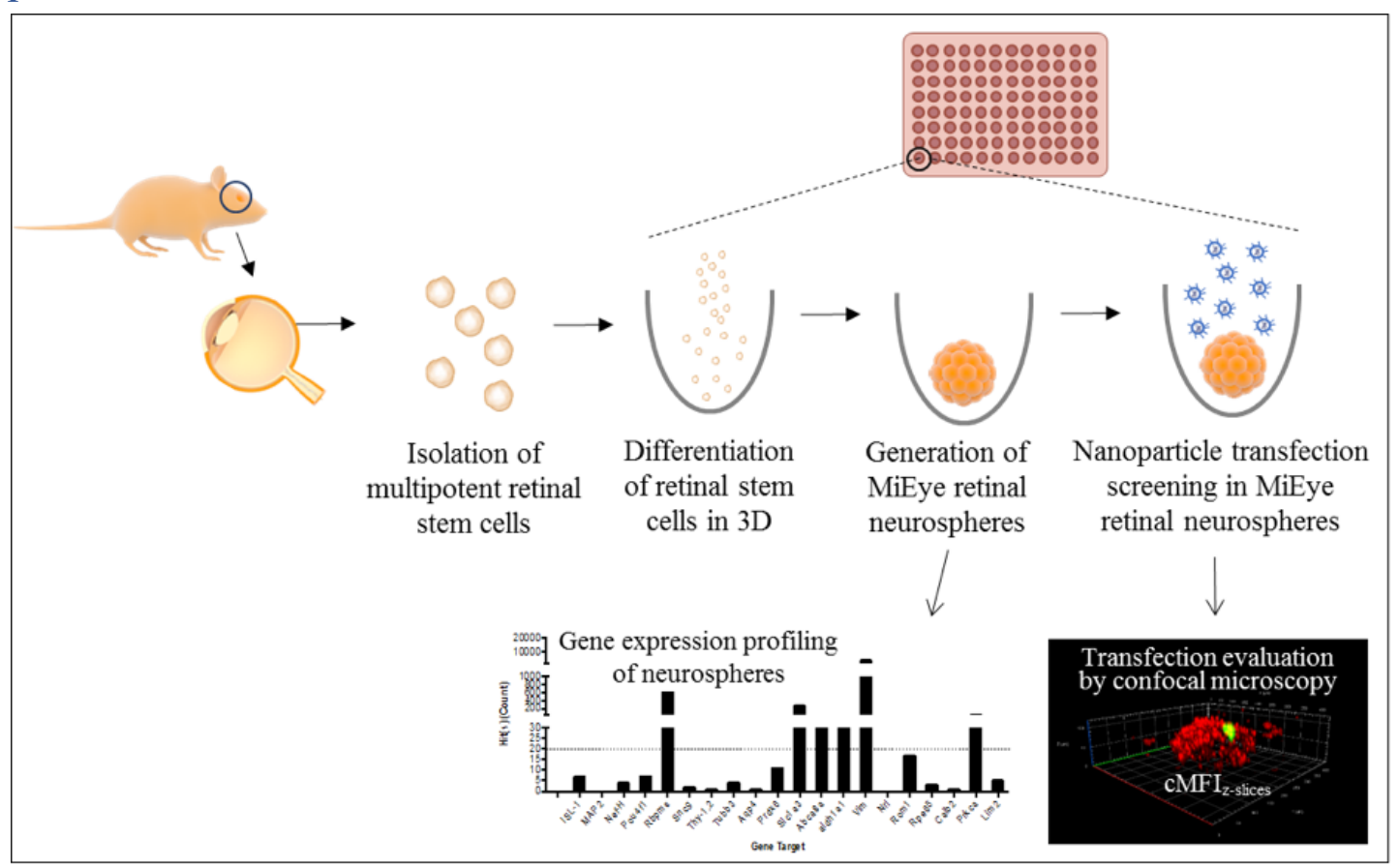

\section{Abstract}

Non-viral retinal gene therapy is a promising therapeutic approach towards the management of retinal degenerative diseases especially glaucoma. Current methods of in vitro preclinical screening of candidate nanoparticle systems in monolayer cell cultures are not reliable in predicting in vivo performance. In this paper we describe the development of a multipotent stem-cell derived threedimensional "mini-retina" culture model (MiEye) that aims to simulate an in vivo clinical model for more reliable gene delivery system screening. Through utilization of multiplex gene expression profiling, we have shown that retinal stem cells can be differentiated in 3D culture to generate retinal neurospheres comprising of multiple retinal cell types. The 3D cell culture model combined with confocal microscopy imaging and fluorescence profiling techniques is a powerful tool as a retinal gene and drug delivery screening model.

\section{Abbreviations:}

- cMFI

Combined mean fluorescence intensity

- $\mathrm{CM}$

Culture medium

- $\mathrm{DM}$

Differentiation medium

a Corresponding Author: Dr. M. Foldvari, D.Pharm.Sci., PhD, FAAPS, Professor of Pharmaceutical Sciences, Director, Drug Delivery and Pharmaceutical Nanotechnology Laboratory, School of Pharmacy, University of Waterloo,200 University Avenue West, Waterloo, ON. Canada N2L 3G, foldvari@uwaterloo.ca 


$\begin{array}{lll}\text { - } & \text { MM } & \text { Maturation medium } \\ \text { - } & \text { RLONP } & \text { K2 nanoparticle } \\ \text { - } & \text { RGC } & \text { poly-L-ornithine } \\ \text { - } & \text { RPE } & \text { Retinal ganglion cell } \\ \text { - } & \text { RSC } & \text { Retinal pigmented epithelium } \\ \text { - } & \text { TE } & \text { Transfection Efficiency } \\ \text { - } & \text { ULA } & \text { Ultra-low attachment }\end{array}$

Keywords: Spheroids, retina, neurosphere, stem cell, 3D culture, gene delivery, non-viral, nanoparticle, glaucoma, retinal ganglion cell, gene expression profiling

\section{Rationale and Purpose}

In a non-viral approach to delivering therapeutic nucleic acids for glaucoma management, a significant challenge lies in efficiently delivering genes into target retinal cells. The majority of non-viral gene delivery systems that have shown highly effective gene transfer capacity in 2D monolayer transfection have failed to translate to comparable levels of gene delivery efficiency in vivo. The gap, in part, is a consequence of the lack of correlation between the results generated from the current standards of transfection efficiency (TE) screening to in vivo feasibility. Recognizing such deficiency, we aimed to bridge this gap through the development of a "mini-retina" neurosphere model composed of major retinal cell types arranged in a three-dimensional (3D) tissue-like architecture. The MiEye retinal neurospheres aim to serve as a retinal model for the rapid screening of transfection capacity of nanoparticle (NP) systems to retinal cells, towards the generation of in vitro results with higher in vivo translatability.

\section{Introduction}

Glaucoma is a neurodegenerative disease of the retina characterized by multifactorial pathophysiology that ultimately results in the loss of retinal ganglion cells (RGCs).[1] A gene therapy approach such as neurotrophic factor gene therapy has the potential to provide extrinsic neurotrophic support that can rescue and protect glaucomatous stressed RGCs.[2,3] Non-viral approaches to deliver therapeutic genes to the retinal cells to carry out therapeutic action for stressed RGCs provides many advantages compared to viral approaches such as lower risk of immunogenicity and mutagenesis, as well as better patient compliance and large-scale manufacturing feasibility.[4]

Despite the large number of NP systems that have demonstrated a high level of TE in vitro, very few demonstrated effectiveness in vivo. An aspect of this is a disconnect between in vitro and in vivo TE screening, suggesting that current standards of in vitro models do not sufficiently predict in vivo performance and feasibility of NPs. The current standards of in vitro NP gene delivery evaluation rely on the assessment of TE in cells cultured in 2D monolayers, which include two major pitfalls in cellular modeling from a gene delivery perspective: (1) a lack of multicellular tissue spatial architecture; and (2) suboptimal representation of NP biodistribution and kinetics.

In retinal degenerative diseases such as glaucoma, cell-cell interactions play an important role in the pathogenesis through various mechanical and molecular factors near the trabecular meshwork and optic nerve head.[5-8] Thus, tissue models such as organotypic explant cultures could greatly benefit the understanding of glaucoma pathogenesis and facilitate gene therapy development using representative models in vivo. Organotypic explants of the retina have been explored by various groups to study pathogenesis and also for drug development purposes.[9-11] However, preparation of retinal explant culture is difficult. While cultivatable for up to two weeks ex vivo, retinal explants spontaneously undergo degeneration upon isolation. 3D retinal models generated from stem cells can yield various retinal cell types along with cellular arrangements similar to the retina $[12,13]$. The ability of stem cells to differentiate autonomously and form the 
optic cup structure in 3D culture models was first demonstrated by Eiraku et al. using mouse embryonic stem cells. [14, 15] Following that, there have also been various attempts to generate retinal organotypic cultures.[16-18] Maekawa et al. have generated retinal organotypic cultures from mouse embryonic stem cells utilizing mouse and human embryonic stem cells.[19]

Another approach in the construction of 3D models has been explored using bioprinting technologies, in which cells are printed based on the desired cellular arrangement. Lorber et al. have demonstrated that retinal stem cells (RSCs) and glial cells of the retina can be printed using 3D printing technology while maintaining viability and neurite outgrowth capacity for both cell types.[20] More recently, a study conducted by Kador et al. demonstrated that by combining 3D printing with radial electrospun scaffolds, they were able to 3D print RGCs onto electrospun surfaces with precise distribution and positioning of RGCs as found in the retina.[21] From a spatial arrangement standpoint, 3D printing-based techniques theoretically possess a comparative advantage as they allow for more control in dictating cellular location on a tissue-like arrangement by "printing" specific cells at specific locations.

While the spatial arrangement of the cells cultured in $3 \mathrm{D}$ culture is either dependent on the resultant conformation from self-aggregation or the conformation dictated by the scaffold onto which the cells adhere. While these various advancements in different tissue modeling approaches are pivotal in developing in vivolike models for many biological and physiological studies, a relatively simpler 3D model is needed for rapid and more predictive screening of non-viral gene delivery systems.

The mouse multipotent retinal stem cells (CD1-4 RSCs) used in this project have previously been described to differentiate into all major retinal cell types in 2D monolayers.[22] In this paper we describe the engineering of 3D spheroids, termed "MiEye" under different culture conditions using the CD1-4 RSCs. The RSCs can be seeded into 96well plates and differentiated into multiple retinal cell types while forming spheroids providing an easily scalable model for retinal gene delivery assessment.

\section{Experimental Design}

The main objective in this investigation was to develop a 3D "mini-retina" model that can be utilized as an in vitro model for the screening of non-viral gene delivery systems. The experimental design focused on two major aspects. First, the generation and optimization of retinal neurospheres from CD-1 RSCs was performed through investigation of various combinations of conditions with the goal of generating structurally stable retinal neurospheres that would contain the most diverse retinal cell types.

The retinal neurospheres (MiEye 1-11) were evaluated using a combination of light microscopic imaging and multiplexed gene expression profiling techniques and the neurosphere with the most optimal properties was selected for screening studies. Second, screening of transfection characteristics of a panel of nine different compositions of a commercially available NP system, K2 ${ }^{\circledR}$ (K2NPs), was conducted in the selected MiEye8 neurosphere and in representative retinal monolayer cells by confocal laser scanning microscopy.

\section{Materials and Methods}

\section{CD1-4 RSC culture}

CD1-4 RSCs isolated from 4 to 8-weeks old CD-1 mice were kindly gifted by Dr. Ting Xie, Stower Institute for Medical Research and University of Kansas. The purified CD1-4 RSCs were cultured in 12-well plates coated with $0.2 \%$ gelatin for 3 hours at $37^{\circ} \mathrm{C}$ and maintained in RSCCM media. Culturing medium for CD1-4 (RSCCM) was composed of advanced DMEM/F12 (Gibco, Thermo Fisher Scientific, Waltham, MA, USA) media with addition of $1.0 \mathrm{~g} / \mathrm{L}$ glucose (Sigma-Aldrich, St. Louis, MO, USA), $1.0 \mathrm{~g} / \mathrm{L}$ lactose (SigmaAldrich), $1.0 \mathrm{~g} / \mathrm{L}$ BSA (Sigma-Aldrich), 0.045 $\mathrm{g} / \mathrm{L}$ proline (Sigma-Aldrich), $2 \mathrm{mM}$ nicotinamide (Sigma-Aldrich), $2 \mathrm{mM} \mathrm{L-}$ glutamate (Gibco), 1\% penicillin/streptomycin (Hyclone), 1\% insulin-transferrin-supplement (Gibco), 5\% knockout serum replacement (Gibco), $20 \mathrm{ng} / \mathrm{mL}$ EGF (Gibco), and $20 \mathrm{ng} / \mathrm{mL}$ bFGF protein (Gibco). Differentiation medium (RSCDM-1) was composed of advanced DMEM/F12 (Gibco) with 2\% B-27 supplement (Gibco), 1\% L-Glutamine (Gibco) and 10 ng/mL bFGF protein (Gibco). RSCDM-1 
containing $1 \% \mathrm{~N}-2$ supplement (Gibco) was named RSCDM-2. Maturation medium was formulated with $2 \mathrm{mM}$ L-Glutamine (Gibco), $2 \%$ B-27 supplement (Gibco), 1\% N-2 supplement (Gibco), $10 \mathrm{ng} / \mathrm{mL}$ bFGF protein (Gibco), and $100 \mathrm{ng} / \mathrm{mL}$ BDNF protein (Peprotech), $10 \quad \mathrm{ng} / \mathrm{mL}$ glial-derived neurotrophic factor protein (Gibco), and 10 $\mathrm{ng} / \mathrm{mL}$ insulin growth factor protein (Gibco) in advanced DMEM/F12, with (RGCMM-3) or without (RGCMM-4), 2\% fetal bovine serum (Thermo Fisher Scientific).

CD1-4 RSCs were cultured on $0.2 \%$ gelatin (Sigma-Aldrich) coated 12-well tissue-culture treated plate for 3 hours at $37{ }^{\circ} \mathrm{C}$. For maturation of retinal neurospheres, culture surfaces were coated with either Matrigel ${ }^{\mathrm{TM}}$ (Corning Incorporated, Corning, NY, USA), or combination of poly-L-ornithine (PLO) (EMD Millipore, Billerica, MA, USA) and laminin (EMD Millipore). For PLO-laminin coating, $0.015 \mathrm{mg} / \mathrm{mL}$ of PLO were prepared in sterile water and applied on to the glass-bottom surface of multi-well plates overnight at room temperature. PLO was then removed and laminin was coated at a concentration of 2 $\mu \mathrm{g} / \mathrm{cm}^{2}$ overnight at $4{ }^{\circ} \mathrm{C}$. For Matrigel ${ }^{\mathrm{TM}}$ coating, $7.6 \mathrm{mg} / \mathrm{mL}$ Matrigel ${ }^{\mathrm{TM}}$ (Corning) was coated on the culture surface at $100 \mu \mathrm{L} / \mathrm{cm}^{2}$ volume, and allowed for gel formation for an hour at $37^{\circ} \mathrm{C}$.

\section{Generation of MiEye retinal neurospheres}

The retinal neurospheres model was established through differentiation of CD1-4 RSCs in commercially available force-floating three-dimensional 96-well ultra-low adhesive (ULA) microplates (Corning). For differentiation of CD1-4 RSCs, 15,000 cells (best seeding density compared to 5,000 and 10,000 cells/well) were seeded into each well of the ULA microplate, and differentiation was carried out using various protocols consisting of different combinations of media, schedules, or surface coating, resulting in the generation of 11 different retinal neurosphere types termed MiEye (1-11) with 2-4 spheres for each. MiEye 1-4 were 24-day differentiated retinal neurospheres, first initiated through differentiation in RSCDM-1 media for 3 days, which was then switched into RSCDM-2 media for 7 more days. Following 10 days of differentiation, spheres were transferred onto either PLO-Laminin or Matrigel ${ }^{\mathrm{TM}}$ coated surface for maturation using either RGCMM-3 or RGCMM-4 media. MiEye5 was an 18-day differentiated retinal neurosphere, first initiated through differentiation in RSCDM-1 media for the first 4 days, followed by differentiation in RSCDM-2 for 14 more days. MiEye7 retinal neurosphere was generated by further maturating the 18-day differentiated spheres on PLO-laminin coated surface for 3 days in RGCMM-4. MiEye8 retinal neurospheres were 6-day differentiated spheres, which were initiated by differentiating in RSCDM- 1 for 2 days. After 2 days of differentiation, the differentiated spheres were changed to RSCDM-2 media for 4 more days. MiEye10 was generated by subjecting MiEye8 to further maturation on PLO-laminin for 4 days in RGCMM-4 media.

\section{NanoString Analysis}

RNA was isolated using a commercially available silica column-based RNA isolation kit, PicoPure RNA Isolation Kit (Arcturus, Thermo Fisher Scientific, Waltham, MA, USA), based on the manufacturer's suggested protocol. Isolated RNA was subjected to gene expression profiling for retinal cell biomarkers using the NanoString nCounter Analysis system, a highly sensitive and reproducible multiplexed mRNA gene expression quantitation method (NanoString, Seattle, Washington, USA). The technology enables direct hybridization of mRNA to its sequencespecific target reporter and capture probe, which allows for the quantitation of mRNA copy number for multiple (up to 800) mRNA sequences simultaneously with high sensitivity for the generation of a gene expression profile.

Retinal biomarker gene expression analysis was performed using a custom code set containing 25 target genes representative of most retinal cell types and housekeeping genes as controls. The panel of target genes includes biomarkers representing major retinal cell types. ISL-1, Map-2, Nef-H, Pou4f1, Rbpms, Sncg, Thy-1.2, and Tubb3 are representative RGC biomarkers; Aqp4, Prdx6 and Slcla 3 are representative astrocyte biomarkers; Abca8a, aldlal, and Vim are representative Müller glia biomarkers; and $\mathrm{Nrl}$ and Roml are representative photoreceptor biomarkers. Rpe65, Calb2, Prkca, and Lim2 each 
individually represent retinal pigment epithelium (RPE), amacrine, bipolar and horizontal cell biomarkers, respectively. Each reaction was analyzed with $100 \mathrm{ng}$ of RNA in a $5 \mu \mathrm{L}$ loading volume, mixed with capture probe and reporter probe. The gene profiling experiment was carried out at the Princess Margaret Genomics Centre (Toronto, Ontario, Canada).

\section{Preparation of K2-NPs}

K2-NPs were formulated by complexing the K2 lipopolyamine-based proprietary transfection reagent (Biontex Laboratories $\mathrm{GmBH}$, München, Germany) with $\mathrm{gWiz}^{\mathrm{TM}}$ green fluorescent protein (GFP) reporter plasmid (Aldevron, Fargo, ND, USA) at various ratios for 30 minutes prior to transfection. K2-DNA v/w ratios from 1:1 to 10:1, DNA dose ranging from 1 to $10 \mu \mathrm{g}$ were formulated and evaluated for TE on the retinal neurospheres. Transfection was carried out by first adding $25 \mu \mathrm{L}$ of $\mathrm{K} 2$ Multiplier into each well for 2 hours. After 2 hours, complexed K2NPs were added into wells. Nine different K2NPs formulations (F1-F9) composed of various combinations of $\mathrm{K} 2$ transfection reagent and DNA concentrations, were prepared for transfection evaluation (Table 1).

Table 1. K2-NPs Formulated for Transfection in MiEye8 Retinal Neurosphere Model

\begin{tabular}{|c|c|c|c|c|}
\hline Formulation & $\begin{array}{c}\text { K2:DNA Ratio } \\
(\mu \mathrm{L}: \mu \mathrm{g})\end{array}$ & $\begin{array}{c}\text { Empirical } \\
\text { K2:DNA Ratio } \\
(\mu \mathrm{L}: \mu \mathrm{g})\end{array}$ & K2 Reagent $(\mu \mathrm{L})$ & DNA $(\mu \mathrm{g})$ \\
\hline F1 & $1: 1$ & $1: 1$ & 1 & 1 \\
\hline F2 & $2: 1$ & $2: 1$ & 4 & 1 \\
\hline F3 & $4: 1$ & $4: 1$ & 10 & 1 \\
\hline F4 & $10: 1$ & $10: 1$ & 20 & 2.5 \\
\hline F5 & $20: 2.5$ & $8: 1$ & 30 & 2 \\
\hline F6 & $30: 5$ & $6: 1$ & 10 & 5 \\
\hline F7 & $10: 2$ & $5: 1$ & 20 & 10 \\
\hline F8 & $20: 5$ & $4: 1$ & 30 & 5 \\
\hline F9 & $30: 10$ & $3: 1$ & & 1 \\
\hline
\end{tabular}

\section{Confocal Laser Scanning Microscopy}

Retinal neurospheres were counterstained with either $5 \mu \mathrm{M}$ Syto $^{\mathrm{TM}} 62$ nuclear stain (Thermo Fisher Scientific, Waltham, MA, USA) or $5 \mu \mathrm{M}$ DRAQ5 ${ }^{\mathrm{TM}}$ nuclear stain (Thermo Fisher Scientific) for 30 minutes at $37^{\circ} \mathrm{C}$ prior to imaging. Neurospheres were imaged using a Zeiss LSM710 confocal laser scanning microscope (Carl Zeiss AG, Oberkochen, Baden-Wü, Germany) with $20 \times$ objective. Three-dimensional images of the spheres were captured using the z-stack functionality in the Zen 2009 software, each constituting 20 optical slices of images through the observable thickness of the retinal neurospheres. Transfection was measured by measuring the GFP expression in the retinal neurospheres. Combined mean fluorescence intensity (cMFI) of retinal neurospheres was obtained by calculating the average of all individual MFIs of optical sections of the neurospheres captured using z-stack. The cMFI of transfected neurospheres was normalized to the MFI of the untreated control neurosphere (background fluorescence). Co-localization between GFP expression and nuclei staining were also assessed using Mander's Overlap Coefficient for each optical slice.

\section{Results}

\section{Generation and characterization of MiEye} retinal neurospheres

Initial studies showed that the undifferentiated CD1-4 RSCs themselves were able to form stem-cell spheres in 3D culture conditions when seeded at cell densities of $5,000,10,000$, and 15,000 cells in ULA spheroid plates. 


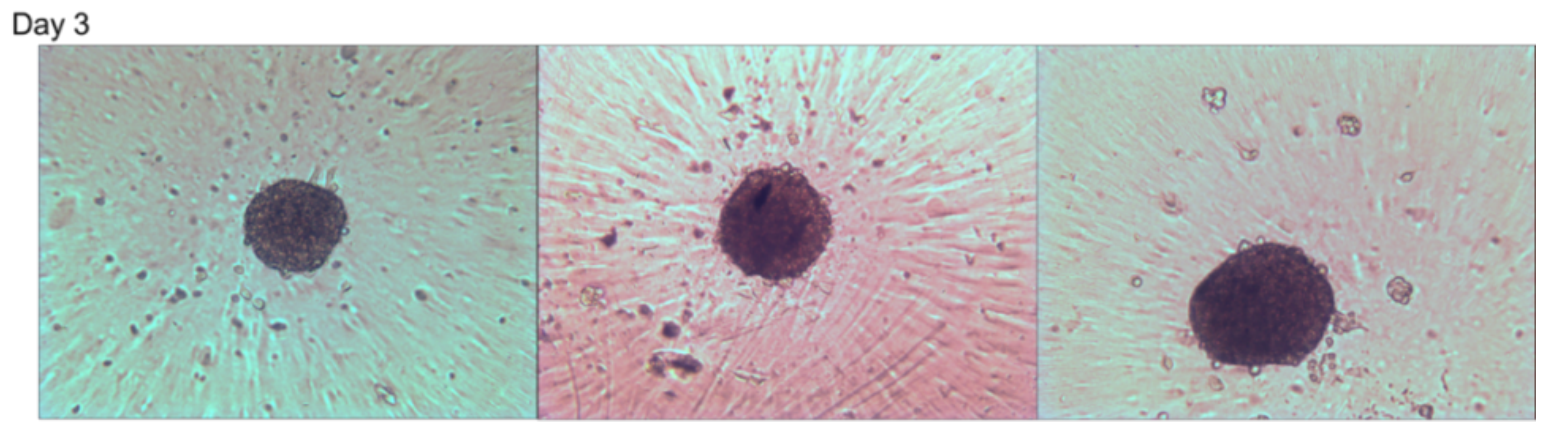

Day 12

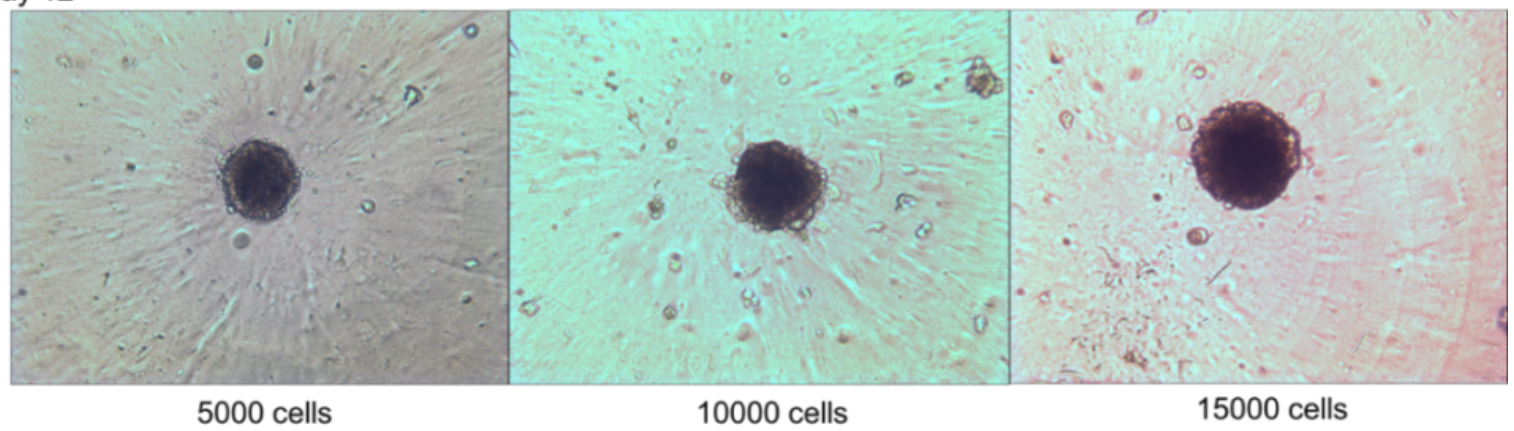

Figure 1. Undifferentiated retinal stem cell-derived retinal neurospheres cultured in ultra-low adhesive spheroid plate at day 3 and 12. Images were captured with $10 \times$ objective using light microscopy.

Spheroids were formed within 24 hours and their morphology was maintained for at least 12 days (Figure 1).

Using a similar approach, retinal neurospheres were initiated by seeding CD1-4 RSCs suspended in differentiation medium in ULA plates. Eleven different MiEye retinal neurospheres were prepared using various protocols (Table 2). A representative workflow of differentiation and maturation is illustrated in Figure 2A and 2B. After culturing of the RSCs for 6-10 days, the formed differentiated neurospheres were allowed to mature on the coated surface (i.e., PLO-laminin) to evaluate the possibility of inducing the formation of morphological features such as neurite extensions. The effect of various combinations of parameters such as retinal neurosphere population $(5,000,10,000$, and 15,000 cells per sphere), maturation medium (serum / no serum), and surface coating (PLOlaminin/Matrigel ${ }^{\mathrm{TM}}$ ) were evaluated on the spheres structural integrity. First, a decrease in seeding cell density from 15,000 cells to 5,000 cells resulted in a decrease in retinal neurosphere structural stability after 2 days of maturation (Figure 3A). Furthermore, the decreased structural stability was more obvious in the presence of Matrigel ${ }^{\mathrm{TM}}$ coating and serum. A decrease in structural stability was evident from size reduction and deformation of the spheres, along with increased monolayer cell attachment on the coated surface surrounding the sphere. Retinal neurospheres were least structurally stable when maturation was taking place in serum-containing maturation media, coupled with Matrigel ${ }^{\mathrm{TM}}$ coated surface, where retinal neurospheres were completely deformed by day 6 (Figure 3B). Seeding density played an important role in the sphere structural stability as retinal neurospheres constructed with only 5,000 cells exhibited complete structural deformation across all culturing conditions by day 6 . The retinal neurospheres made with 10,000 cells matured in serum-containing medium on either PLO-Laminin or Matrigel ${ }^{\mathrm{TM}}$ coated surface also showed significant deformation. However, retinal neurospheres matured in medium without serum on either PLO-Laminin or Matrigel $^{\mathrm{TM}}$ coated surface showed greater structural integrity. The retinal neurospheres made with 15,000 cells maintained the highest structural integrity after 6 days of maturation on various coated surface and media. 
Matrigel $^{\mathrm{TM}}$ and PLO-laminin coated surfaces produced significantly different effect on retinal neurosphere integrity profile over 6 days. Maturation on Matrigel ${ }^{\mathrm{TM}}$ resulted in 4 out of 6 retinal neurospheres showing significant structural integrity decline with significant deformation and size reduction after 2 days. By the 6th day, 5 out of 6 maturation conditions resulted in near-complete deformation of retinal neurospheres. On the other hand, PLO-laminin coated surfaces support retinal neurosphere structural destabilization with all 6 retinal neurosphere maturation conditions showing no sign of structural destabilization after 2 days.

A)

CD1-4 retinal stem cell differentiation

15,000 cells seeding density

Differentiation in ULA plate

Maturation on Matrigel $(0.45 \mathrm{mg} / \mathrm{mL})$ coated glass-bottom plate

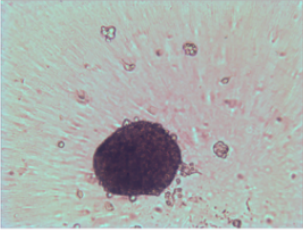

Day 3

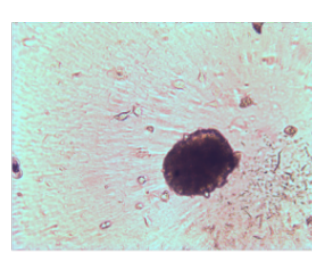

Day 12
- Matrigel coated surface

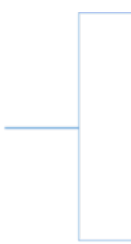

- Matrigel coated surface Supplement
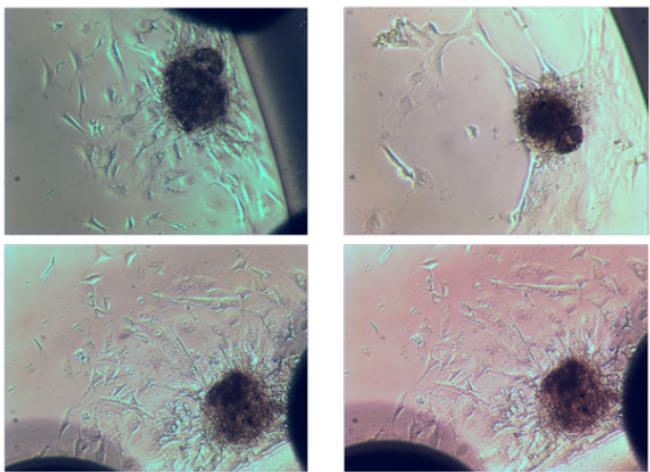

Day 14

Maturation on PLO-Laminin coated glass-bottom ( 6 days)

Day 12

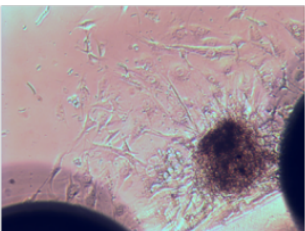

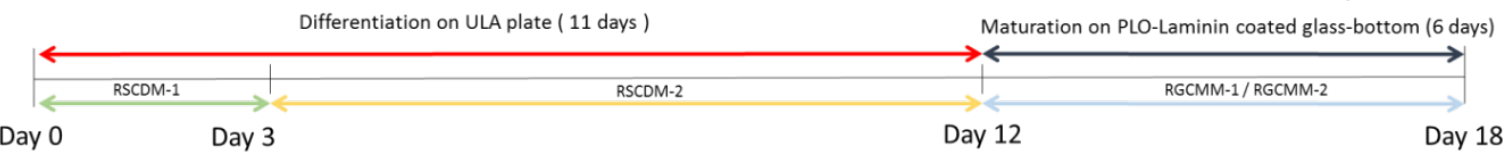

B)

CD1-4 retinal stem cell differentiation

15,000 cells seeding density

Differentiation in ULA plate

Maturation on PLO-Laminin coated glass-bottom plate

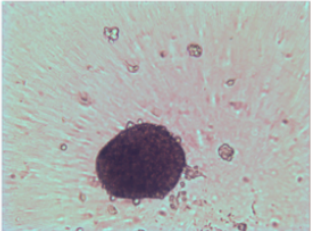

Day 3
- PLO-Laminin coated$$
\text { - } \begin{gathered}
\text { surface } \\
\text { No FBS }
\end{gathered}
$$

- NoFBS

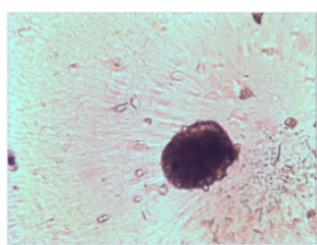

Day 12

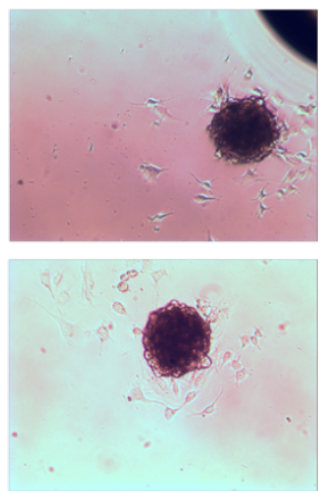

Day 14

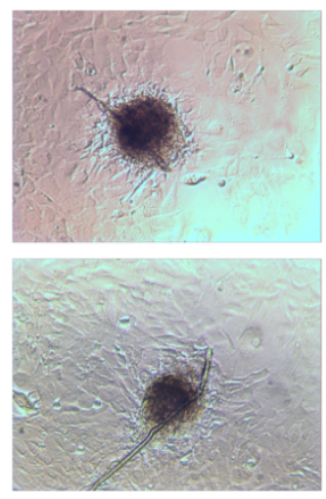

Day 18

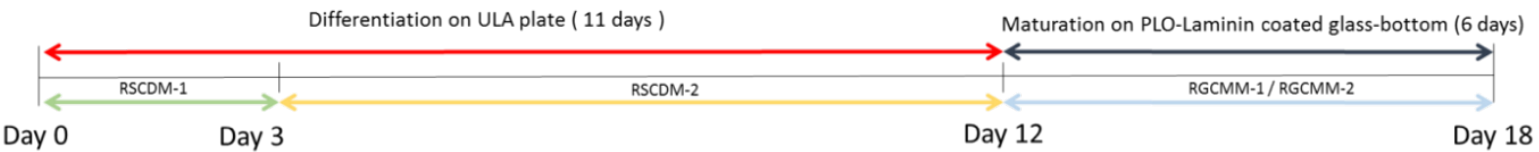

Figure 2. Representative differentiation and maturation process of retinal stem cells towards the generation of differentiated retinal neurosphere on Matrigel ${ }^{\mathrm{TM}}(A)$ and PLO-laminin (B) coated surface. Images were captured with 10x objective using light microscopy. $F B S=$ fetal bovine serum; $U L A=$ ultra-low attachment. 
A)

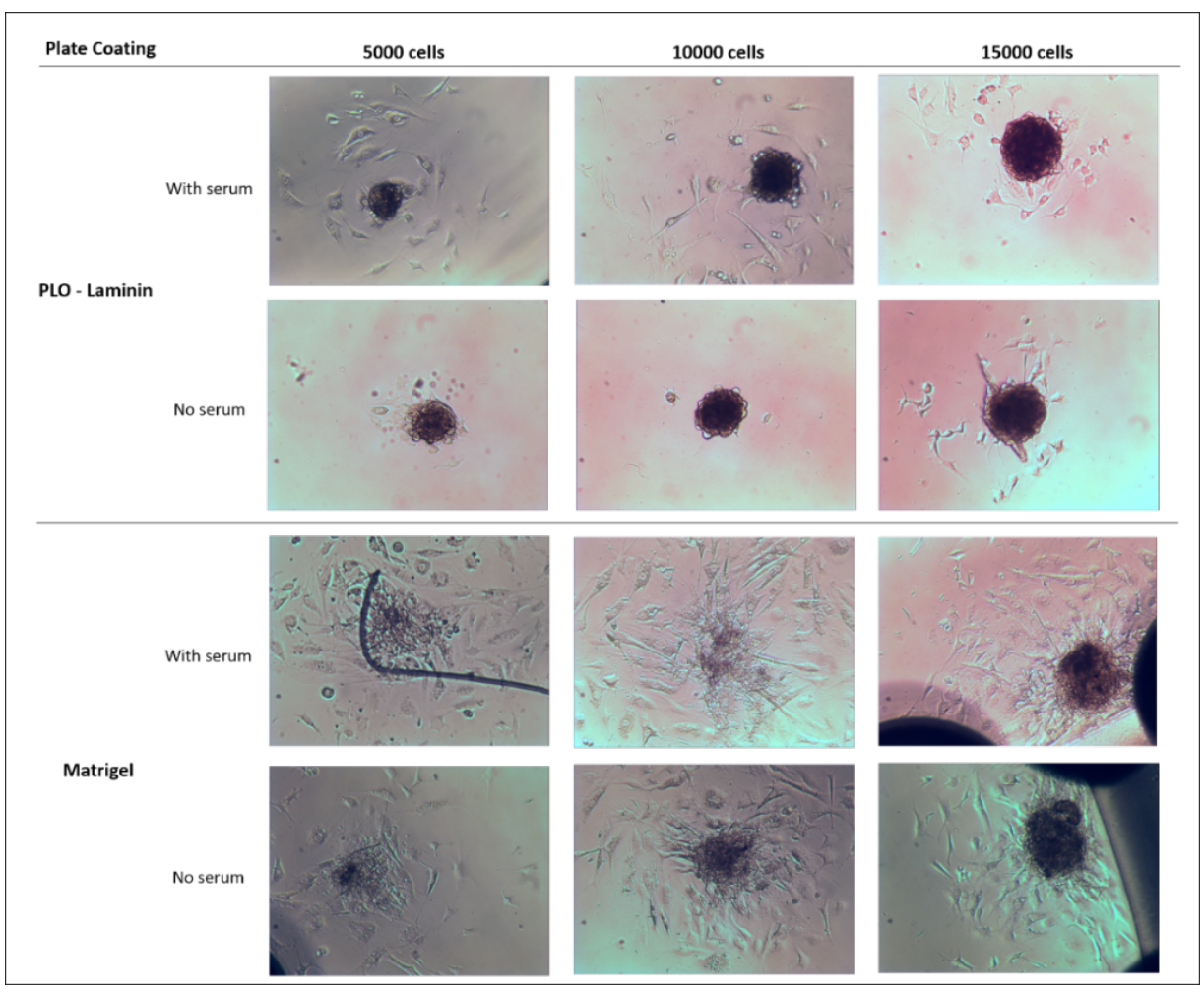

B)

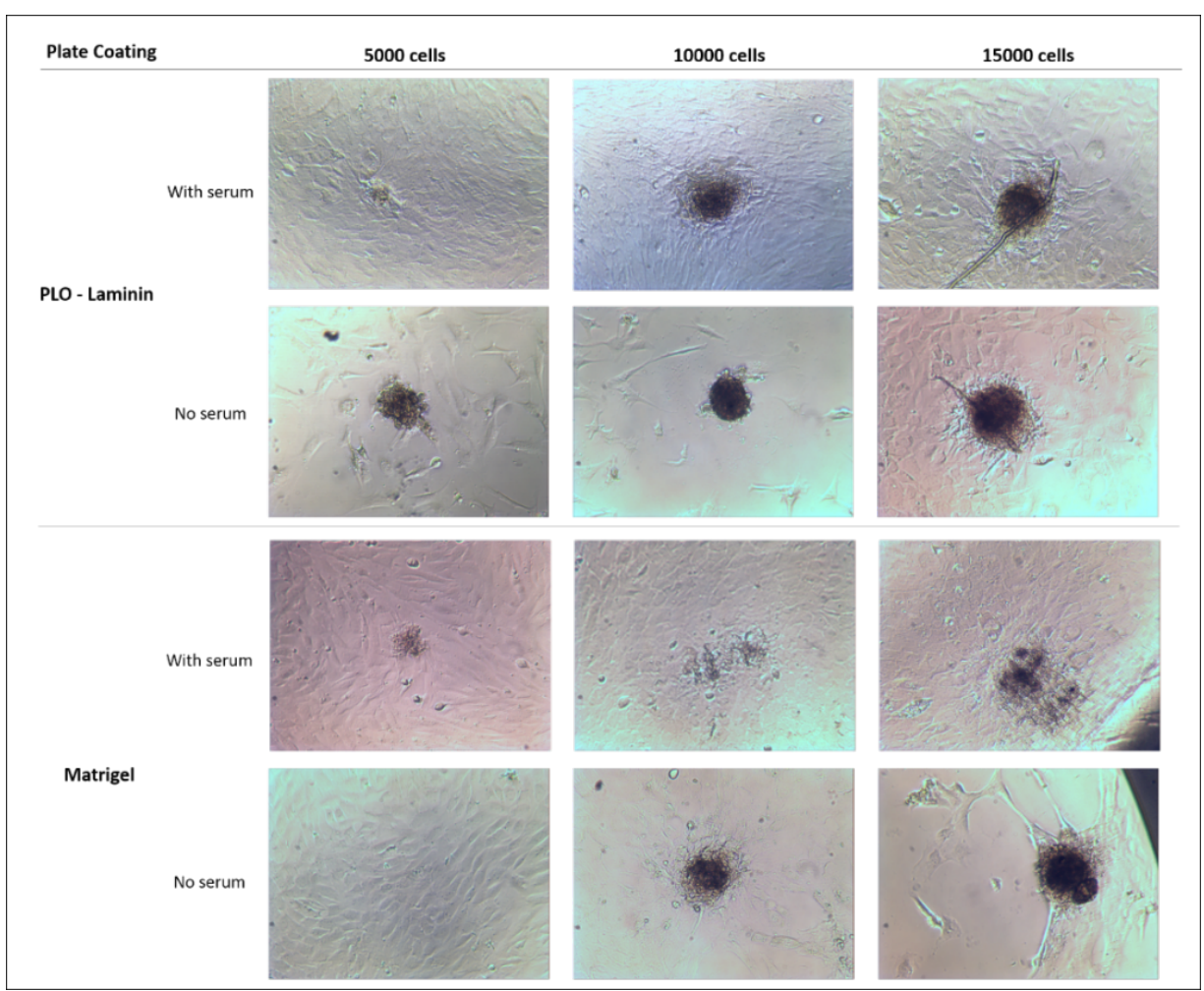

Figure 3. Effect of neurosphere size on the maintenance of structural integrity during the maturation process on PLOlaminin and Matrigel coated surfaces, with or without serum for 2 days (A) and 6 days (B). Images were captured with $10 \times$ objective using light microscopy. 
Furthermore, 4 of the 6 maturation conditions showed minimal structural de-stabilization after 6 days. As it was determined that retinal neurospheres with 15,000 cells were able to provide the highest morphological integrity, downstream experimentations and evaluations were carried out using 15,000 cell seeding density, and 8 MiEye retinal neurospheres (MiEye1, MiEye2, MiEye3, MiEye4, MiEye5, MiEye7, MiEye8, MiEye10) were considered viable from the various combinations of differentiation and maturation conditions (Table 2).

Table 2. Overview of MiEye Retinal Neurosphere Differentiation and Maturation Parameters.

\begin{tabular}{|c|c|c|c|c|c|c|}
\hline \multirow{2}{*}{ Name } & \multirow{2}{*}{ Description } & \multicolumn{2}{|c|}{ Differentiation } & \multicolumn{3}{|c|}{ Maturation } \\
\hline & & Days & Media & Days & Media & Surface \\
\hline MiEye1 & $\begin{array}{c}\text { 24-day } \\
\text { differentiation - } \\
\text { protocol\#2 }\end{array}$ & 10 & $\begin{array}{l}\text { RSCDM-1 (D0-3) } \\
\text { RSCDM-2 (D3-10) }\end{array}$ & 12 & RGCMM-3 & PLO-Laminin \\
\hline MiEye2 & $\begin{array}{c}\text { 24-day } \\
\text { differentiation - } \\
\text { protocol\#2 }\end{array}$ & 10 & $\begin{array}{l}\text { RSCDM-1 (D0-3) } \\
\text { RSCDM-2 (D3-10) }\end{array}$ & 12 & RGCMM-4 & PLO-Laminin \\
\hline MiEye3 & $\begin{array}{c}\text { 24-day } \\
\text { differentiation - } \\
\text { protocol\#2 }\end{array}$ & 10 & $\begin{array}{l}\text { RSCDM-1 (D0-3) } \\
\text { RSCDM-2 (D3-10) }\end{array}$ & 12 & RGCMM-3 & Matrigel \\
\hline MiEye4 & $\begin{array}{c}\text { 24-day } \\
\text { differentiation - } \\
\text { protocol\#2 }\end{array}$ & 10 & $\begin{array}{l}\text { RSCDM-1 (D0-3) } \\
\text { RSCDM-2 (D3-10) }\end{array}$ & 12 & RGCMM-4 & Matrigel \\
\hline MiEye5 & $\begin{array}{c}\text { 18-day } \\
\text { differentiation - } \\
\text { protocol\#3 }\end{array}$ & 18 & $\begin{array}{l}\text { RSCDM-1 (D0-4) } \\
\text { RSCDM-2 (D4-18) }\end{array}$ & - & - & - \\
\hline MiEye6 & $\begin{array}{c}\text { 21-day } \\
\text { differentiation - } \\
\text { protocol \#3 }\end{array}$ & 18 & $\begin{array}{l}\text { RSCDM-1 (D0-4) } \\
\text { RSCDM-2 (D4-18) }\end{array}$ & 3 & RGCMM-3 & PLO-Laminin \\
\hline MiEye 7 & $\begin{array}{c}\text { 21-day } \\
\text { differentiation - } \\
\text { protocol \#3 }\end{array}$ & 18 & $\begin{array}{l}\text { RSCDM-1 (D0-4) } \\
\text { RSCDM-2 (D4-18) }\end{array}$ & 3 & RGCMM-4 & PLO-Laminin \\
\hline MiEye8 & $\begin{array}{c}\text { 6-day } \\
\text { differentiation - } \\
\text { protocol \#4 }\end{array}$ & 6 & $\begin{array}{l}\text { RSCDM-1 (D0-2) } \\
\text { RSCDM-2 (D2-6) }\end{array}$ & - & - & - \\
\hline MiEye9 & $\begin{array}{c}\text { 6-day } \\
\text { differentiation - } \\
\text { protocol \#5 }\end{array}$ & 6 & RSCDM-2 (D0-6) & - & - & - \\
\hline MiEye10 & $\begin{array}{c}\text { 10-day } \\
\text { differentiation - } \\
\text { protocol\#4 }\end{array}$ & 6 & $\begin{array}{l}\text { RSCDM-1 (D0-2) } \\
\text { RSCDM-2 (D2-6) }\end{array}$ & 4 & RGCMM-4 & PLO-Laminin \\
\hline MiEye11 & $\begin{array}{c}\text { 10-day } \\
\text { differentiation - } \\
\text { protocol \#5 }\end{array}$ & 6 & RSCDM-2 (D0-6) & 4 & RGCMM-4 & PLO-Laminin \\
\hline
\end{tabular}

$\mathrm{RGCMM}=$ retinal ganglion cell maturation medium; RSCDM = retinal stem-cell differentiation medium

Based on biomarker mRNA gene expression profiling, retinal neurospheres MiEye1, Mieye2, Mieye 3 and Mieye4, positively expressed multiple biomarkers that represent 7 different retinal cell types (Table 3). Several target genes were expressed across the 4 retinal neurospheres such as Rbpms, Slcla31, Aldhlal, Vim, Rom, and Prkca. Selective biomarker such as Tubb3 was also positively expressed in MiEye 1 (Figure 4A) and MiEye3 (Figure 4C), but not in MiEye2 (Figure 4B) and MiEye4 (Figure 4D). Abca8a was positively expressed in MiEye1, MiEye3 and MiEye4, but not in MiEye2. Rpe65 and Prdx6, were detected to be expressed at low levels but did not meet the 20 copies thresholds in MiEye1, MiEye2, MiEye3, MiEye4, respectively. All 4 retinal neurospheres positively expressed 8 different 
markers including Rbpms, Tubb3. Based on the gene expression profile results, these 4 differentiated populations expressed the markers for most of the retinal cell types such as RGC, astrocyte, Müller glia, photoreceptor, RPE, amacrine and bipolar cells, suggesting the possibility that the retinal neurospheres contained all these major retinal cell types.

MiEye5 (Figure 4E) was an 18-day differentiated retinal neurosphere, and MiEye7 (Figure 4F) was differentiated with the 18-day differentiation protocol with an additional 3day protocol on PLO-laminin surface. Both retinal neurospheres showed very different expression profiles. MiEye5 positively expressed 6 gene targets with differential mRNA copies of Rbpms, Slcla3, Abca8a, Aldhlal, Vim and Prkca. On the other hand, MiEye7 positively expressed only 4 gene targets, Rbpms, Slcla3, Vim, and Prkca, with relatively lower copy numbers.

Table 3. Retinal Biomarker mRNA Expression Profile Summary for MiEye Retinal Neurospheres. Heat map categorizes gene expression into 3 major categories: no expression $(\mathrm{n}<5$; blue), semi-positive expression $(5<\mathrm{n}<20$; pink), and positive expression ( $\mathrm{n}>20$; red).

\begin{tabular}{|c|c|c|c|c|c|c|c|c|c|c|}
\hline $\begin{array}{l}\text { Gene } \\
\text { Specifi- } \\
\text { city }\end{array}$ & Gene & $\begin{array}{l}\text { Six- day } \\
\text { Differ- } \\
\text { entiated } \\
\text { CD1-4 }\end{array}$ & MiEye1 & MiEye2 & MiEye3 & MiEye4 & MiEye5 & MiEye7 & MiEye8 & MiEye10 \\
\hline \multirow[t]{9}{*}{ RGC } & CD48 & 5 & 7 & 2 & 1 & 3 & 2 & 4 & 5 & 2 \\
\hline & ISL-1 & 6 & 3 & 8 & 1 & 9 & 5 & 3 & 7 & 2 \\
\hline & MAP2 & 2 & 4 & 1 & 2 & 8 & 0 & 0 & 0 & 0 \\
\hline & Nef-H & 0 & 1 & 0 & 3 & 1 & 1. & 0 & 4 & 1 \\
\hline & Pou4f1 & 2 & 2 & 5 & 2 & 1 & 0 & 2 & 7 & 2 \\
\hline & Rbpms & 527 & 675 & 620 & 606 & 855 & 362 & 120 & 601 & 120 \\
\hline & Sncg & 3 & 0 & 2 & 3 & 5 & 2 & 0 & 2 & 1 \\
\hline & Thy-1.2 & 2 & 3 & 0 & 1 & 0 & 1 & 0 & 1 & 0 \\
\hline & Tubb3 & 40 & 25 & 17 & 61 & 10 & 1 & 3 & 4 & 4 \\
\hline \multirow[t]{3}{*}{$\begin{array}{l}\text { Astro- } \\
\text { cyte }\end{array}$} & Aqp4 & 1 & 1 & 0 & 3 & 2 & 3 & 2 & 1 & 2 \\
\hline & Prdx6 & 4 & 9 & 12 & 11 & 10 & 7 & 1 & 11 & 3 \\
\hline & Slc1a3 & 272 & 925 & 762 & 734 & 724 & 162 & 24 & 268 & 54 \\
\hline \multirow[t]{3}{*}{$\begin{array}{c}\text { Müller } \\
\text { glial }\end{array}$} & Abca8a & 7 & 36 & 15 & 41 & 34 & 28 & 1 & 31 & 4 \\
\hline & aldh1a1 & 31 & 204 & 166 & 157 & 200 & 44 & 9 & 40 & 12 \\
\hline & Vim & 16544 & $\begin{array}{c}1411 \\
5\end{array}$ & 16081 & 16150 & 18974 & 3865 & 2583 & 3860 & 1519 \\
\hline \multirow[t]{2}{*}{$\begin{array}{l}\text { Photo- } \\
\text { receptor }\end{array}$} & $\mathrm{Nrl}$ & 1 & 0 & 2 & 1 & 3 & 0 & 0 & 0 & 0 \\
\hline & Rom1 & 30 & 23 & 25 & 29 & 33 & 13 & 2 & 17 & 4 \\
\hline RPE & Rpe65 & 9 & 8 & 5 & 10 & 11 & 14 & 10 & 3 & 9 \\
\hline $\begin{array}{l}\text { Amac- } \\
\text { rine }\end{array}$ & Calb2 & 5 & 5 & 5 & 3 & 5 & 5 & 3 & 1 & 3 \\
\hline Bipolar & Prkca & 104 & 140 & 152 & 120 & 151 & 32 & 32 & 53 & 14 \\
\hline $\begin{array}{l}\text { Hori- } \\
\text { zontal }\end{array}$ & $\operatorname{Lim} 2$ & 0 & 0 & 0 & 2 & 0 & 0 & 0 & 5 & 1 \\
\hline
\end{tabular}

$\mathrm{RGC}=$ retinal ganglion cells; $\mathrm{RPE}=$ retinal pigment epithelium. 
A.

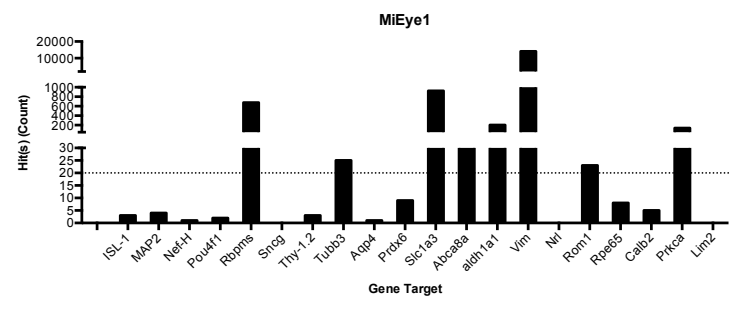

C.

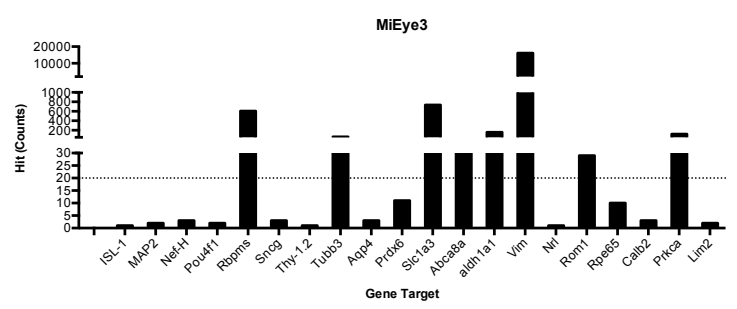

E.

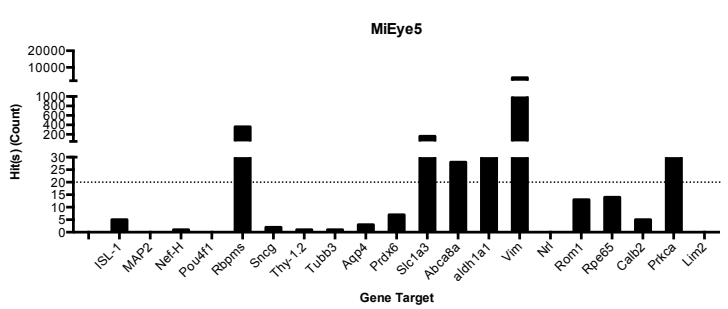

G.

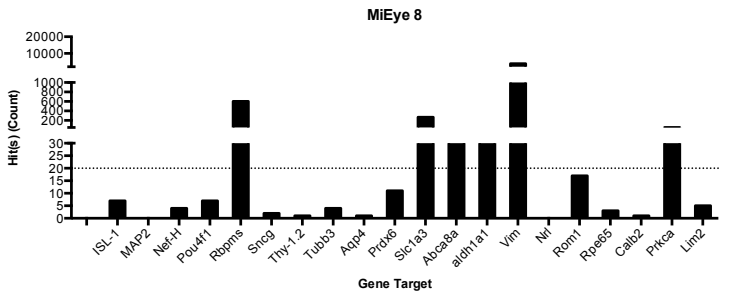

B.

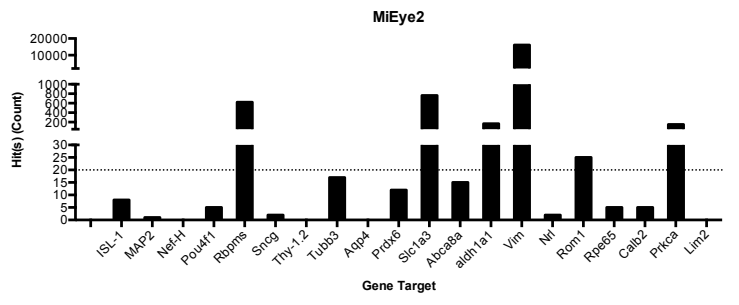

D.

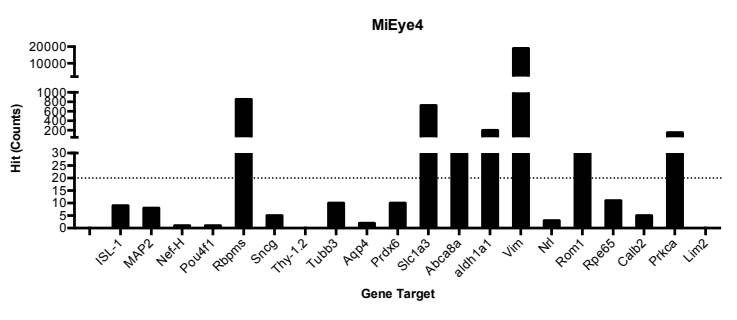

F.

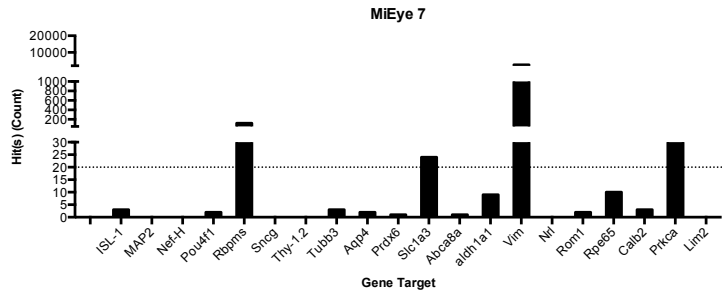

H.

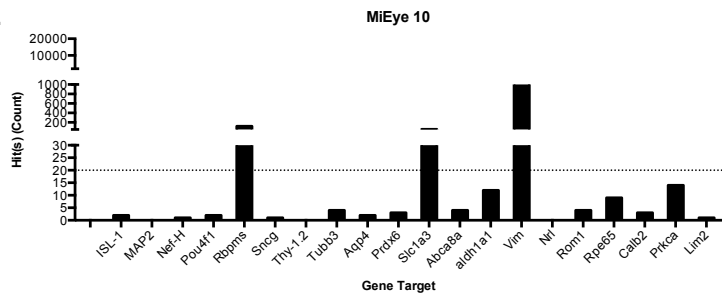

Figure 4. Retinal biomarker mRNA gene expression profiles of retinal neurospheres MiEye1 (A), MiEye2 (B), MiEye3 (C), MiEye4 (D), MiEye5 (E), MiEye7 (F), MiEye8 (G), and MiEye10 (H). Threshold indicator (dotted lines) at $n=20$ is indicative of the threshold for positive expression.

MiEye8 (Figure 4G) was a 6-day differentiated retinal neurosphere, and MiEye10 (Figure 4H) was generated from the same 6-day differentiation protocol with an additional 4 days of maturation process on PLO-laminin surface. MiEye8 positively expressed 6 target genes Rbpms, Slcla3, Abca8a, Aldh1a1, Vim, and Prkca. On the other hand, MiEye10 positively expressed only 3 target genes, Rbpms, Slcla3, and Vim, at relatively lower expression levels.

Among the retinal neurospheres generated, MiEye8 retinal neurosphere was chosen as a model retinal neurosphere to demonstrate the proof of concept for transfection studies as it showed similarities in differentiated retinal cell type compositions compared to the 6-day differentiated CD1-4 RSCs in monolayers that was described in previously published work.[22] From the biomarker expression profile perspective, both 6-day differentiated CD1-4 cells in monolayer and 6-day differentiated CD1-4 in 3D (MiEye8) showed they consists of multiple target cell types such as astrocyte, Müller glial, RGC, and bipolar 


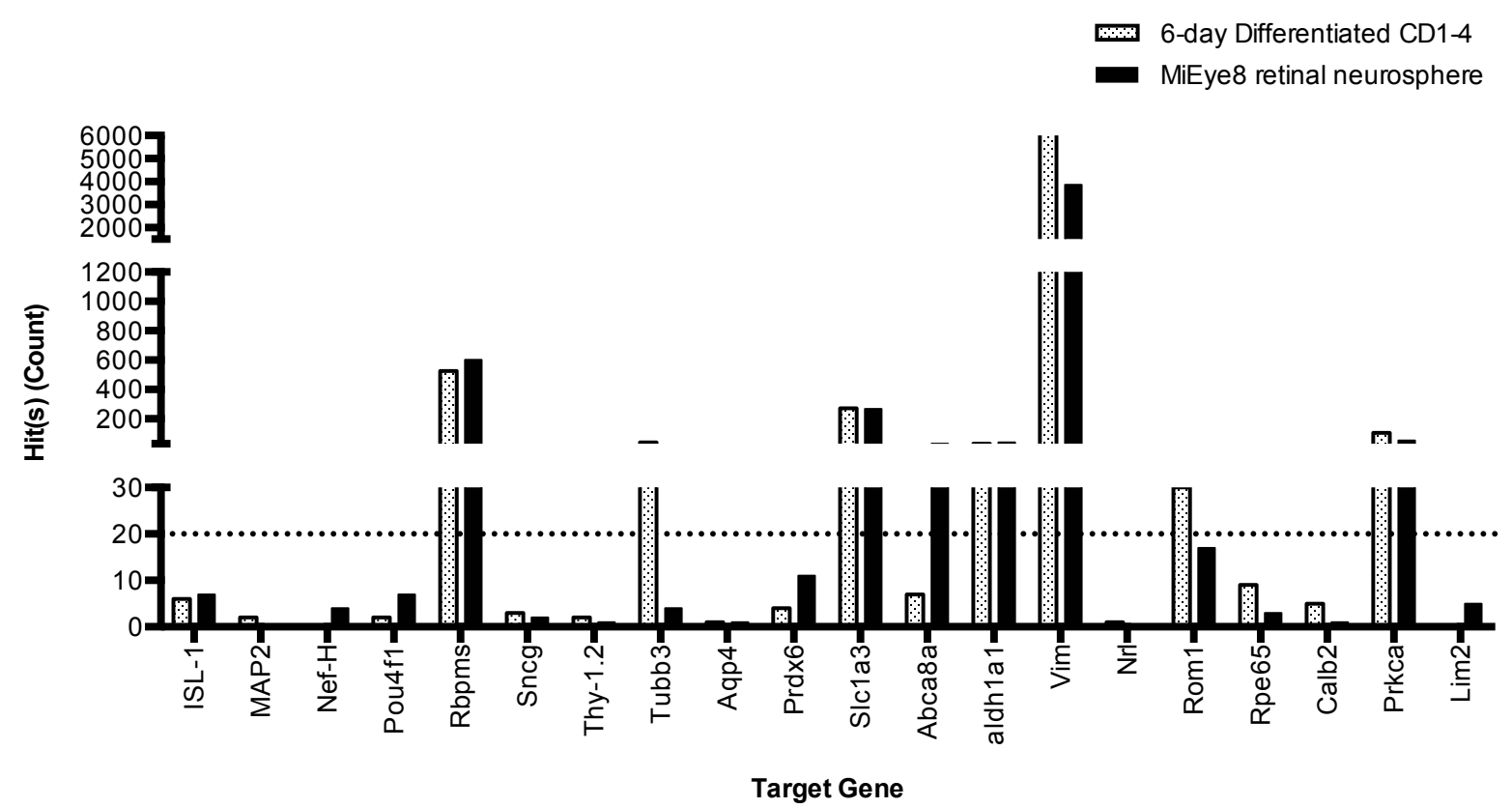

Figure 5. Comparative mRNA gene expression profile analysis of 6-day differentiated CD1-4 stem cells in monolayers and MiEye8 retinal neurospheres.

cells as they both expresses retinal target genes Rbpms, Slcla3, aldhlal, Vim, and Prkca at similar levels (Figure 5). Tubb3, Rom1, genes, Abca8 a biomarkers were expressed at different levels between 2-D and neurosphere, with 10fold, 1.8-fold, and 4.4-fold differences, respectively.

\section{Transfection screening of K2-NP non- viral gene delivery systems in MiEye retinal neurospheres}

Transfection of MiEye8 retinal neurospheres was carried out using K2-NPs, a non-viral gene delivery system shown to have high TE in astrocytes and RGCs cultured in monolayer in our previous studies.[23] Nine formulations of K2-NPs were prepared and screened in the MiEye8 retinal neurospheres. Among the different treatments, neurospheres transfected with F3 (4:1 v/w K2:DNA ratio) and F4 (10:1 $\mathrm{v} / \mathrm{w}$ K2:DNA ratio) K2-NPs were able to transfect the neurospheres as demonstrated by confocal microscopic observations of GFP expression (Table 4). Transfection was further assessed by quantitative evaluation of MFI captured in the GFP channel throughout the thickness of retinal neurospheres. In untreated retinal neurospheres, all cells remained intact and no detached cells or cell aggregates were found outside of the neurospheres. Following treatment with K2-NPs using increasing concentrations of $\mathrm{K} 2$ reagent, increasing number of detached cells and cell debris were present around neurospheres, which we have interpreted as increasing levels of toxicity (Table 4).

In the MiEye8 retinal neurosphere transfected with F3, localized gene expression was observed in the superficial layers of the neurosphere (Figure 6A). This was also evident through analysis of $\mathrm{Z}$-stack optical slices (Figure 6B), where GFP expression was visible between optical slices 4 to 9 . The MFI profile for specific regions of interest, as shown in Figure $6 \mathrm{C}$ and $\mathrm{D}$, illustrates presence of GFPexpressing cells. Quantitative analysis of optical slices 4-9 indicated that the cMFI of F3transfected neurosphere were up to 7-fold higher compared to the control neurosphere (Figure 6E). The cMFI throughout the thickness of the F3-transfected neurosphere was 36.0 \pm 55.7 . Retinal neurospheres transfected with F4 (10:1 v/w K2:DNA ratio) showed a widely scattered GFP expression pattern on the surface of the retinal neurosphere (Figure 7A). 
Table 4. Transfection Screening of a Panel of K2-NP Formulations in MiEye8 Retinal Neurosphere, CD1-4 Derived RGC Monolayer, and A7 Astrocyte Monolayer

\begin{tabular}{|c|c|c|c|c|c|c|}
\hline & \multicolumn{6}{|c|}{ Retinal Cell Models } \\
\hline & \multicolumn{2}{|c|}{$\begin{array}{l}\text { MiEye8 Retinal } \\
\text { Neurosphere }\end{array}$} & \multicolumn{2}{|c|}{ CD1-4 Derived RGC Monolayer [24] } & \multicolumn{2}{|c|}{$\begin{array}{r}\text { A7 Astrocyte } \\
\text { Monolayer [23] }\end{array}$} \\
\hline $\begin{array}{l}\text { K2-NP } \\
\text { Formulation }\end{array}$ & $\begin{array}{c}\text { cMFI of } \\
\text { GFP } \\
\text { Channel* } \\
\text { (Normalized } \\
\text { to Baseline) }\end{array}$ & $\begin{array}{l}\text { Observed } \\
\text { Toxicity }\end{array}$ & Transfection Efficiency** & $\begin{array}{c}\text { Cell } \\
\text { Viability }\end{array}$ & $\begin{array}{l}\text { Transfection } \\
\text { Efficiency** }\end{array}$ & $\begin{array}{c}\text { Cell } \\
\text { Viability }\end{array}$ \\
\hline $\mathrm{F} 1$ & - & + & $\mathrm{n} / \mathrm{a}$ & $\mathrm{n} / \mathrm{a}$ & - & $\mathrm{n} / \mathrm{a}$ \\
\hline $\mathrm{F} 2$ & - & + & $63.1 \pm 1.4 \%$ & $94.4 \pm 0.4$ & $15.8 \pm 2.6 \%$ & $76.2 \pm 1.7$ \\
\hline F3 & $36.0 \pm 55.7$ & + & $62.9 \pm 1.9 \%$ & $79.7 \pm 3.3$ & $31.3 \pm 1.5 \%$ & $44.8 \pm 2.2$ \\
\hline $\mathrm{F} 4$ & $91.9 \pm 30.5$ & ++ & $\mathrm{n} / \mathrm{a}$ & $\mathrm{n} / \mathrm{a}$ & $\mathrm{n} / \mathrm{a}$ & $\mathrm{n} / \mathrm{a}$ \\
\hline F5 & - & ++ & $\mathrm{n} / \mathrm{a}$ & $\mathrm{n} / \mathrm{a}$ & $\mathrm{n} / \mathrm{a}$ & $\mathrm{n} / \mathrm{a}$ \\
\hline F6 & - & ++ & $\mathrm{n} / \mathrm{a}$ & $\mathrm{n} / \mathrm{a}$ & $\mathrm{n} / \mathrm{a}$ & $\mathrm{n} / \mathrm{a}$ \\
\hline F7 & - & +++ & $\mathrm{n} / \mathrm{a}$ & $\mathrm{n} / \mathrm{a}$ & $\mathrm{n} / \mathrm{a}$ & $\mathrm{n} / \mathrm{a}$ \\
\hline F8 & - & +++ & $\mathrm{n} / \mathrm{a}$ & $\mathrm{n} / \mathrm{a}$ & $\mathrm{n} / \mathrm{a}$ & $\mathrm{n} / \mathrm{a}$ \\
\hline F9 & - & +++ & $\mathrm{n} / \mathrm{a}$ & $\mathrm{n} / \mathrm{a}$ & $\mathrm{n} / \mathrm{a}$ & $\mathrm{n} / \mathrm{a}$ \\
\hline
\end{tabular}

Transfection efficiency evaluations:

*combined average of the individual MFI (cMFI) of all optical sections of the neurospheres ( $\mathrm{n}=9-12$; number of sections vary depending on the exact size of each sphere)

**data from flow cytometry measurements (mean $\pm \mathrm{SD} ; \mathrm{n}=3$ ) - no transfection

Observed toxicity evaluations:

+ low toxicity level with minimal debris

++ medium toxicity level with some debris near neurosphere

+++ significant toxicity level with lots of debris and noticeable disintegration of neurosphere

$\mathrm{cMFI}=$ combined mean fluorescence intensity; GFP = green fluorescent protein .

Analysis of z-stack optical slices show that GFP expressions was observed scattered across the sphere in optical slices 4 to 11 (Figure 7B). MFI analysis showed that the neurosphere transfected with F4 consistently have higher MFI (up to 1.71-fold) compared to untreated control. The cMFI throughout the thickness of the neurosphere was $91.9 \pm 30.5$. Similarly, MFI profiling in a selected region of interest shows peaks corresponding to GFP-expressing cells along the line (Figure 7C and D).

\section{Discussion}

Eight retinal neurospheres with distinct retinal gene expression profiles were generated using various differentiation procedures. Through gene expression profiling, it was evident that CD1-4 RSCs were able to differentiate in 3D culture, generating retinal neurospheres composed of various retinal cell types including RGCs, astrocytes, Müller glial and photoreceptor cells, depending on the differentiation procedure. 


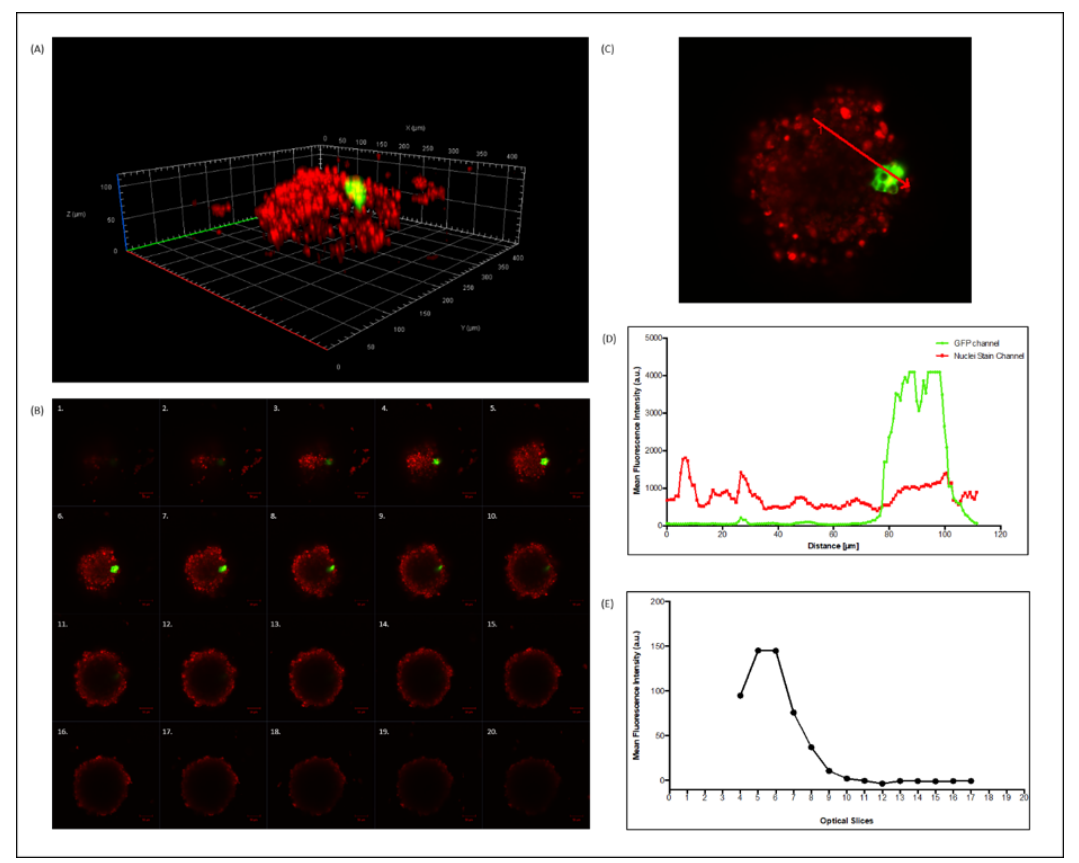

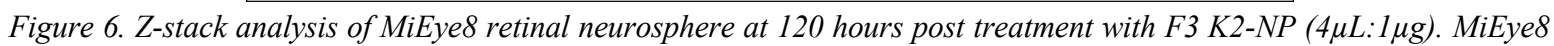
retinal neurosphere was counterstained with $5 \mu M$ of DRAQ5 green fluorescent protein (GFP) expression (green). A) 3D reconstruction of the MiEye8 retinal neurosphere demonstrating GFP expression in the neurosphere surface layer. B) 20 z-stack optical slices captured across the observable thickness of the retinal neurosphere showing visible GFP expression in slices 4 to 9. C) Representative illustration MFI analysis on GFP and nuclei stain channels through a region of interest (red arrow) on an optical section (slice 6) of the neurosphere. Blunt end of the arrow marks the start of the path $(0 \mu \mathrm{m})$ and the tip of the arrow marks the end of the path $(111 \mu \mathrm{m})$. The corresponding GFP (green) and nuclei stain (red) channel MFI through the path of interest is shown in (D). E) Normalized average GFP channel MFI of the neurosphere in each optical section throughout the z-stack.

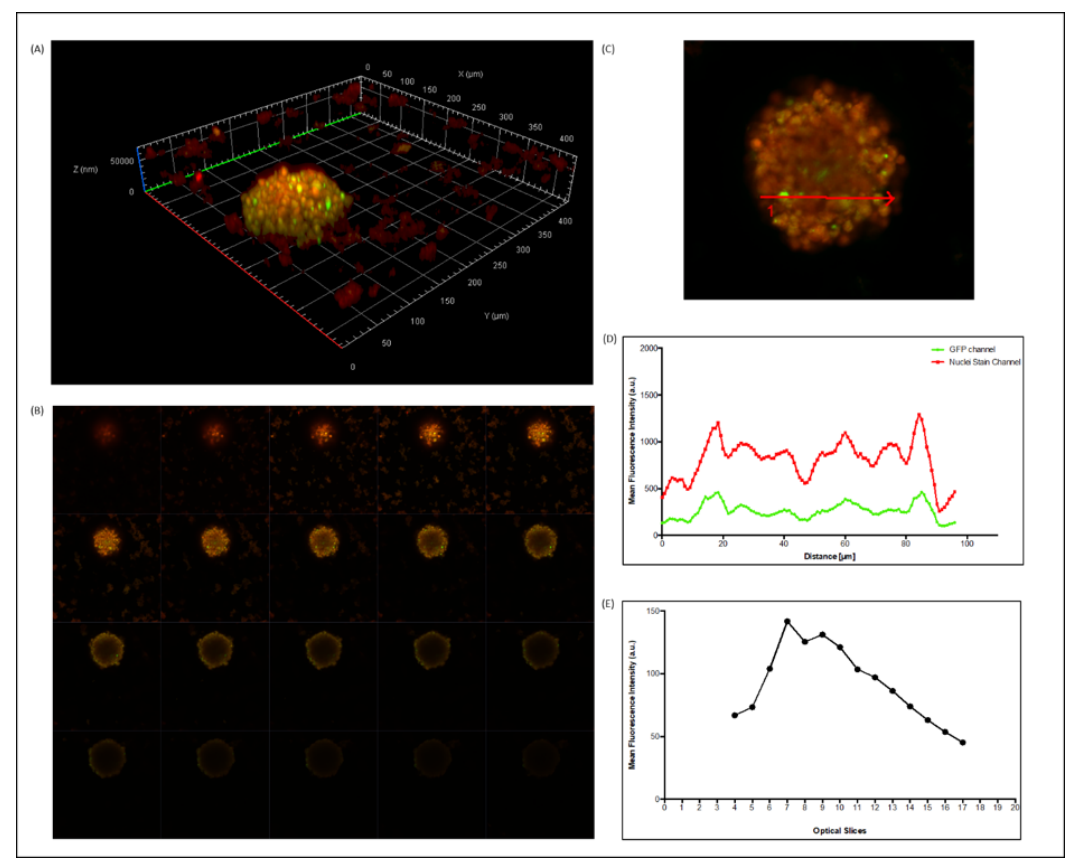

Figure 7. Z-stack analysis of MiEye8 retinal neurosphere at 120 hours post treatment with F4 K2-NP (10 $\mu$ L:1 $\mu \mathrm{g})$. MiEye8 retinal neurosphere were counterstained with $5 \mu M$ of Syto ${ }^{\mathrm{TM}} 62$ nuclei stain (red). Successful transfection is indicated by green fluorescent protein (GFP) expression (green). A) 3D reconstruction of the MiEye8 retinal neurosphere demonstrating GFP expression on neurosphere surface. B) 20 z-stack optical slices captured across the observable thickness of the retinal neurosphere showing visible GFP expression in slices 4 to 9. C) Representative illustration of mean fluorescence intensity (MFI) analysis on GFP and nuclei stain channels through the region of interest (red arrow) on an optical section (slice 7) of neurosphere. Blunt end of the arrow marks the start of the path $(0 \mu \mathrm{m})$ and the tip of the arrow marks the end of the path (96 $\mu \mathrm{m})$. The corresponding GFP (green) and nuclei stain (red) channel MFI through the path of interest is shown in (D). E) Normalized average GFP channel MFI of the neurosphere in each optical section throughout the z-stack. 
Of particular interest, the 6-day differentiated CD1-4 RSCs in either 2D or 3D showed similar diversity of cells through gene expression profiles as both expresses key biomarkers for astrocytes, Müller glial, astrocyte, and bipolar cells at similar levels. The presence of mixed cell types in retinal neurosphere cultures may allow for versatile downstream gene delivery system assessment options such as transfection, infiltration, and targeting efficiencies.

Using the MiEye8, a 6-day differentiated retinal neurosphere expressing markers of RGC, astrocyte, Müller glial, photoreceptor and bipolar cells, K2-NPs with various compositions were screened. The K2-NP system was a highly effective gene delivery reagent in $2 \mathrm{D}$ monolayers as demonstrated in our previous work, where K2-NP formulation with K2:DNA ratio of $4: 1$ at $1 \mu \mathrm{g}$ pDNA per dose showed $60 \%$ TE in monolayer XFC RGCs (Table 4).[23] In MiEye8, K2-NPs with the same K2:DNA ratios of $4: 1$ at $1 \mu \mathrm{g}$ pDNA per dose (F3) showed lower TE and the transfection was localized to the surface cellular layers of the neurosphere. K2-NP formulation (F4) with $\mathrm{K} 2$ :DNA ratios of 10:1 at $1 \mu \mathrm{g}$ pDNA per dose also showed lower transfection compared to cells in monolayers, but with a more uniformly scattered pattern across the surface of the neurosphere. In both cases, transfected cells were localized on the surface of the sphere with very limited signs of gene expression in the interior of the spheres. Increasing the K2:DNA ratio and DNA per dose did not improve the TE; however, toxicity increased. More specifically, higher concentrations of $\mathrm{K} 2$ transfection reagent resulted in higher toxicity, as observed by the increasing amounts of cellular debris around the spheres. Differences in NP toxicity profile have also been observed between 3D neurospheres and 2D cell monolayers, as neurospheres appear to have higher resistance to NP toxicity compared to cells cultured in 2D monolayers. For example, in the case of F3 K2NP transfection, CD1-4 derived RGCs and A7 cells culture in 2D monolayer were more susceptible to toxicity compared to MiEye8 neurosphere.

Assessment of the gene delivery capacity of NPs through evaluation of the cMFI of neurospheres is an alternative approach to flow cytometry of individual cells from 2-D cultures as it measures the relative level of a reporter protein that is produced by transfected cells. Utilizing fluorescence intensity and cMFI as a means of evaluating neurospheres in this paper has allowed the characterization of transfection by K2-NPs. Such evaluation of TE analysis could also be applied in other forms of tissuelike cultures and in vivo to approximate $\mathrm{TE}$, where dissociation of tissue structure into individual cells for single-cell transfection analysis is inefficient and challenging.

As expected, TE of cells in 3D were significantly lower $(\sim 2 \sim 4 \%)$ compared to cell 2D monolayer (15-63\%) in cells transfected with the same NP system, which could be attributed to several factors. One of the major differences in a 3D culture-based assay is the architectural and spatial properties. From a cellnano exposure perspective, traditional 2D monolayer culture allows for higher cell-nano exposure, where cell populations are distributed across the culture surface and can be exposed to NPs more uniformly. In 3D culture, on the other hand, lower cell-nano exposure can be attributed to the tissue-like cellular arrangement, where the outermost cell layers have the highest cell-nano contact with gradual decrease with increasing depth towards the center of the sphere. Aside from architectural and spatial factors, cell proliferation factors could also influence transfection. The majority of the commonly used cell lines for in vitro studies are immortalized cell lines that proliferate at a high rate in cell culture, while primary cells and cells found in vivo either do not proliferate or typically proliferate at a much lower rate. Various studies over the years have shown that cell cycle plays a role in gene delivery, particularly for non-viral based NPs that lack the efficient transduction machinery unlike viruses.[26] Moreover, the difficult part of transfection is not necessarily cellular entry, but rather translocation of pDNA to the nucleus.[26] Delivery of pDNA before mitosis has been suggested to increase the level of transgene expression,[27, 28] and has been suggested that transfection during cell division results in significantly higher level of expression in part due to nuclear envelope split, thus assisting pDNA in nuclear entry.[29] As cells in MiEye8 constitute tissue-like multicellular arrangement coupled with limited proliferation capacity compared to immortalized cell lines that divide indefinitely, 
it therefore captures key characteristics of cells in vivo, in an in vitro modality. Altogether, the combinations of various in vivo-relevant structural and cellular properties, retinal neurospheres such as MiEye8 have the potential to serve as a tool for predicting in vivo performance of NPs. It is recognized that a 3D retinal model that consists of a complete representation of the retinal cell type diversity, arrangements, and functions of the retina could be an important tool for the understanding of retinal biology and retinal therapeutic discovery. The significance of the MiEye retinal model described in this paper is twofold: (1) the model is an important first step towards the generation of a complete retina model; and (2) the model demonstrates the potential towards the generation of a more in vivo translatable preclinical screening model for NP-mediated gene delivery.

\section{Conclusion}

In summary, this paper demonstrates the development of a 3D retinal neurosphere model. Among neurospheres grown in 11 different culture conditions, a 6-day differentiated neurosphere, MiEye8, have shown value as a "mini-retina"-like model that contains the major retinal cell types and can be used towards a more in vivo-relevant screening of non-viral gene delivery systems.

\section{Acknowledgement}

The authors thank Monika Sharma and Neil Winegarden of the Princess Margaret Genomic Centre for their help with NanoString analysis. The research in this paper was supported by operating and equipment grants from the Canadian Institutes of Health Research, the Natural Sciences and Engineering Research Council of Canada, the Canada Foundation for Innovation and the Ontario Research Fund. The generous support of the Canada Foundation for Innovation, the Ontario Research Fund and the Canada Research Chairs Program is also gratefully acknowledged (M. Foldvari).

\section{Conflict of Interests}

The authors declare no conflicts of interest. For signed statements, please contact the journal office: editor@precisionnanomedicine.com

Quote as: Chen DW, Foldvari M. Retinal Multipotent Stem-Cell Derived "MiEye" Spheroid 3D Culture Model for Preclinical Screening of Non-viral Gene Delivery Systems. Prec. Nanomed. 2018 July;1(2):106-123 DOI: $10.29016 / 180711.1$

\section{References}

[1] M. Almasieh, A.M. Wilson, B. Morquette, J.L. Cueva Vargas, A. Di Polo, The molecular basis of retinal ganglion cell death in glaucoma, Prog Retin Eye Res, 31 (2012) 152-181.

[2] K.R.G. Martin, H.A. Quigley, D.J. Zack, H. Levkovitch-Verbin, J. Kielczewski, D. Valenta, L. Baumrind, M.E. Pease, R.L. Klein, W.W. Hauswirth, Gene Therapy with Brain-Derived Neurotrophic Factor As a Protection: Retinal Ganglion Cells in a Rat Glaucoma Model, Investigative Opthalmology \& Visual Science, 44 (2003) 4357.

[3] A. Wilson, A. Di Polo, Gene therapy for retinal ganglion cell neuroprotection in glaucoma, Gene therapy, 19 (2012) 127-136.

[4] M. Foldvari, D.W. Chen, N. Nafissi, D. Calderon, L. Narsineni, A. Rafiee, Non-viral gene therapy: Gains and challenges of non-invasive administration methods, Journal of Controlled Release, (2015).

[5] J.C. Downs, M.D. Roberts, I.A. Sigal, Glaucomatous cupping of the lamina cribrosa: a review of the evidence for active progressive remodeling as a mechanism, Experimental eye research, 93 (2011) 133-140.

[6] A.F. Clark, The cell and molecular biology of glaucoma: biomechanical factors in glaucoma, Investigative ophthalmology \& visual science, 53 (2012) 2473-2475.

[7] M.R. Hernandez, H. Miao, T. Lukas, Astrocytes in glaucomatous optic neuropathy, Progress in brain research, 173 (2008) 353-373. 
[8] E.C. Johnson, J.C. Morrison, Friend or foe? Resolving the impact of glial responses in glaucoma, Journal of glaucoma, 18 (2009) 341.

[9] N. Bull, T. Johnson, K. Martin, Organotypic explant culture of adult rat retina for in vitro investigations of neurodegeneration, neuroprotection and cell transplantation, Protoc exch, (2011).

[10] S. Gustmann, N. Dünker, In vivo-like organotypic murine retinal wholemount culture, Journal of visualized experiments: JoVE, (2010).

[11] T.V. Johnson, K.R. Martin, Development and characterization of an adult retinal explant organotypic tissue culture system as an in vitro intraocular stem cell transplantation model, Investigative ophthalmology \& visual science, 49 (2008) 3503-3512.

[12] J.S. Meyer, R.L. Shearer, E.E. Capowski, L.S. Wright, K.A. Wallace, E.L. McMillan, S.-C. Zhang, D.M. Gamm, Modeling early retinal development with human embryonic and induced pluripotent stem cells, Proceedings of the National Academy of Sciences, 106 (2009) 16698-16703.

[13] J.S. Meyer, S.E. Howden, K.A. Wallace, A.D. Verhoeven, L.S. Wright, E.E. Capowski, I. Pinilla, J.M. Martin, S. Tian, R. Stewart, Optic vesicle-like structures derived from human pluripotent stem cells facilitate a customized approach to retinal disease treatment, Stem cells, 29 (2011) 1206-1218.

[14] M. Eiraku, N. Takata, H. Ishibashi, M. Kawada, E. Sakakura, S. Okuda, K. Sekiguchi, T. Adachi, Y. Sasai, Self-organizing optic-cup morphogenesis in three-dimensional culture, Nature, 472 (2011) $51-56$

[15] T. Nakano, S. Ando, N. Takata, M. Kawada, K. Muguruma, K. Sekiguchi, K. Saito, S. Yonemura, M. Eiraku, Y. Sasai, Self-Formation of Optic Cups and Storable Stratified Neural Retina from Human ESCs, Cell Stem Cell, 10 (2012) 771-785.

[16] H.Y. Chen, K.D. Kaya, L. Dong, A. Swaroop, Three-dimensional retinal organoids from mouse pluripotent stem cells mimic in vivo development with enhanced stratification and rod photoreceptor differentiation, Mol. Vision, 22 (2016) 1077.

[17] M. Völkner, M. Zschätzsch, M. Rostovskaya, R.W. Overall, V. Busskamp, K. Anastassiadis, M.O. Karl, Retinal organoids from pluripotent stem cells efficiently recapitulate retinogenesis, Stem cell reports, 6 (2016) 525-538.

[18] A.W. Browne, C. Arnesano, N. Harutyunyan, T. Khuu, J.C. Martinez, H.A. Pollack, D.S. Koos, T.C. Lee, S.E. Fraser, R.A. Moats, Structural and Functional Characterization of Human Stem-CellDerived Retinal Organoids by Live Imaging, Investigative Ophthalmology \& Visual Science, 58 (2017) 3311-3318.

[19] Y. Maekawa, A. Onishi, K. Matsushita, N. Koide, M. Mandai, K. Suzuma, T. Kitaoka, A. Kuwahara, C. Ozone, T. Nakano, Optimized culture system to induce neurite outgrowth from retinal ganglion cells in three-dimensional retinal aggregates differentiated from mouse and human embryonic stem cells, Current eye research, 41 (2016) 558-568.

[20] B. Lorber, W.-K. Hsiao, I.M. Hutchings, K.R. Martin, Adult rat retinal ganglion cells and glia can be printed by piezoelectric inkjet printing, Biofabrication, 6 (2013) 015001.

[21] K.E. Kador, S.P. Grogan, E.W. Dorthé, P. Venugopalan, M.F. Malek, J.L. Goldberg, D.D. D'lima, Control of retinal ganglion cell positioning and neurite growth: Combining 3D printing with radial electrospun scaffolds, Tissue Engineering Part A, 22 (2016) 286-294.

[22] T. Li, M. Lewallen, S. Chen, W. Yu, N. Zhang, T. Xie, Multipotent stem cells isolated from the adult mouse retina are capable of producing functional photoreceptor cells, Cell research, 23 (2013) 788-802.

[23] D.W. Chen, M. Foldvari, In vitro bioassay model for screening non-viral neurotrophic factor gene delivery systems for glaucoma treatment, Drug delivery and translational research, 6 (2016) 676-685.

[24] D.W. Chen, M. Foldvari, Characterization of retinal ganglion cells derived from multipotent stem cells as tools for neurotrophic factor gene therapy system development, In Preparation, (2018).

[25] E.R. Shamir, A.J. Ewald, Three-dimensional organotypic culture: experimental models of mammalian biology and disease, Nature reviews Molecular cell biology, 15 (2014) 647-664. 
[26] J. Zabner, A.J. Fasbender, T. Moninger, K.A. Poellinger, M.J. Welsh, Cellular and molecular barriers to gene transfer by a cationic lipid, Journal of Biological Chemistry, 270 (1995) 18997-19007.

[27] W.-C. Tseng, F.R. Haselton, T.D. Giorgio, Mitosis enhances transgene expression of plasmid delivered by cationic liposomes, Biochimica et Biophysica Acta (BBA)-Gene Structure and Expression, 1445 (1999) 53-64.

[28] I. Mortimer, P. Tam, I. MacLachlan, R. Graham, E. Saravolac, P. Joshi, Cationic lipid-mediated transfection of cells in culture requires mitotic activity, Gene therapy, 6 (1999).

[29] M. Männistö, M. Reinisalo, M. Ruponen, P. Honkakoski, M. Tammi, A. Urtti, Polyplex-mediated gene transfer and cell cycle: effect of carrier on cellular uptake and intracellular kinetics, and significance of glycosaminoglycans, The journal of gene medicine, 9 (2007) 479-487. 